$\mathbb{T}$ periodica polytechnica

\author{
Social and Management Sciences

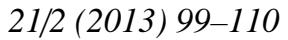 \\ doi: 10.3311/PPso.7087 \\ http://periodicapolytechnica.org/so \\ Creative Commons Attribution (i) \\ RESEARCH ARTICLE \\ László György / Dóra Sebestyén \\ Received 2012-09-25
}

\section{Solving the 'Malay Problem' in Singapore - A Lesson for Hungary: Focus on change in attitude}

\begin{abstract}
The 'Malay Problem', an expression often used by Malay leaders, gradually began to spread within the Malay community in Singapore in 1971 when it was first used. This expression refers to and includes educational underachievement, drug abuse, disadvantaged and dysfunctional families, poor socioeconomic standing and low skills of Malay workers. After a short introduction of the 'Roma issue' in Hungary, the aim of this study is to introduce the joint efforts undertaken by Malay leaders and the government of Singapore to cope with the challenges emerging within the context of the 'Malay problem' in Singapore.

Lessons to learn from this study are as follows: focusing simultaneously on change in attitude within the underprivileged minority combined with support from the majority of the society can help close the achievement gap. Focusing only on one of these two factors, however, would be insufficient based on the double-looped-vicious-circle concept. This study provides detailed insight on how Singapore narrowed the achievement gap between Malays and non-Malays, and it provides policy advice related to Hungarian efforts based on the success of Singaporean Malays.
\end{abstract}

\section{Keywords}

closing the achievement gap · 'Roma issue' · 'Malay problem'

\section{László György}

Budapest Universityof Technology and Economics, Department of Finance, Magyar tudósok körútja 2., 1117 Budapest, Hungary

e-mail: gyorgy@ finance.bme.hu

\section{Dóra Sebestyén}

Budapest Universityof Technology and Economics, Department of Finance, Magyar tudósok körútja 2., 1117 Budapest, Hungary

e-mail: dori.sebestyen@gmail.com

\section{Introduction}

We chose to examine the process of solving the 'Malay problem' in Singapore as one of the most successful achievement gap closing efforts in recent decades. First, we introduce the similarities between the 'Malay problem' and the 'Roma issue' to demonstrate that the two challenges are very similar in their root causes and symptoms. Second, we turn to the process of solving the 'Malay problem' in Singapore. Finally, we compare Singapore's approach to the problem and Hungary's approach of trying to close the achievement gap between Roma and nonRoma (National Societal Achievement Gap Closing Strategy, Action Plan 2012-14, Nemzeti Társadalmi Felzárkózási Stratégia, Intézkedési Terv 2012-14 [2]). Our aim is to help Hungarian decision makers fine-tune their concept. Our hypothesis is that recent achievement gap closing efforts and current efforts in Hungary focus more on external factors and less on the internal inertia of the underprivileged minority, while a more balanced concept would result in greater benefits to Roma integration efforts.

\section{Similarities between the 'Malay Problem' in Singa- pore and the 'Roma Issue' in Hungary}

Hungary is facing a similar challenge to that faced by Singapore since the beginning of the 1960s. The difference between the two is found in the extent of the problem. The share of the Malay minority in Singapore were approximately $7 \%$ in the beginning of the 1970s, while in Hungary, the share of Roma was approximately 2.7 to $3.7 \%$ (Kemény [15]). The numbers for Hungary were even lower, though statistically undocumented, at the beginning of the 1960s when both countries first began to address the achievement gap problem. The ratio of Malays in Singapore increased to $13.4 \%$, while the ratio of Roma in Hungary increased to approximately $10 \%$. While Singapore has an exact register on the nationality of its citizens, we can only rely on guesstimates regarding the ratio of the Roma population in Hungary as information on religion and nationality is regarded as sensitive in Europe and in Hungary (LXXVII Law in 1993). Based on these guesstimates the ratio of Roma was between 7 to $14 \%$ in 2011 (MC 2011, BCE 2011). 


\section{'Malay Problem'}

'The emergence of the (Malay) problem was primarily the consequence of (British) colonial history, and in part, the internal inertia of the Malay community itself. The continued deprivation of the Malays is considered a 'problem' in relation to the growing prosperity and affluence of the non-Malays. British pre-occupation with their own trade and commerce and their benign neglect of the Malays, especially in education, deprived the Malays of the knowledge and know-how of modern business and commercial activities. This resulted in the widening of the socio-economic gap between the Malays and the non-Malays' (Wan 1990: 12 in Kassim [14, p. 11]).

The Malay problem expression often used by Malay leaders gradually began to spread within the Malay community in 1971 when the expression was first used. This expression refers to and includes educational underachievement, drug abuse, disadvantaged and dysfunctional families, poor socio-economic standing and low skills of Malay workers. 'Although the Malay Problem is essentially an economic one, focus was given to education since the Malay leaders view it as the impetus to overcome the other issues related to the Malay Problem' (Kassim [14, p. 7]).

Although the seminar 'Malay Participation in the National Development of Singapore' held in May 1971 discussed the problems facing the Singapore Malays, it was multi-racial in composition. The organisers believe that 'the problems of the Malays are not communal or racial in character, but that they are a national problem. (...) With the non-Malays accepting the fact their help is for the long-term national good, and with the Malays knowing that although a minority, they have a place in Singapore, a path towards national integration is assured' (Sharom Ahmat \& James Wong, Malay Participation in the National Development of Singapore, 1971: 1 [35] in Kassim).

\section{'Roma Issue'}

The origins of the Roma issue are highly debated even within the research community.

According to one of the two approaches, most Roma adhere to the customs and traditions of their ancestors, which significantly differ from the customs of the majority of the Hungarian society. Customs common to the Roma, for example, include marrying early, having many children ${ }^{1}$, and building vigorously on the greater family ties when raising children and when entering into the workforce. Furthermore, the Roma culture places a higher value on knowledge attained through the parent-child relation-

\footnotetext{
${ }^{1}$ The Hungarian welfare system included relatively generous child-related direct transfers (Gábos et al. [8]) until 2010. According to the supposition of some scholars and professionals, the reason behind the high fertility rate among Roma transubstantiated from cultural to socio-economic. Because the Hungarian social security system has been subsidising the undertaking of children at a relatively high amount during the last two decades, it focused on Roma's high fertility rate while having no positive effect on the non-Roma majority's fertility rate.
}

ship than on knowledge attained through the educational system, which is considered secondary. According to some commentaries, the Roma follow a less modern/more traditional lifestyle, a lifestyle that can be characterised by the epoch before the so-called demographic transition (Németh [26], Neményi [25]). According to the words of Sándor Romano Rácz [32], a Roma intellectual, the Roma represent the 'culture of the uninvolved', a people who have never wanted to integrate.

The paramount causes of the underprivileged status among the Roma are the dysfunctional operations of its institutions, which are led by the majority of the society, the insensitivity and impatience of representatives/opinion leaders to deviate from the norms of the majority, the local and central political symbols that fixate on the everyday prejudices and, above all, the media's (primarily television's) role in exaggerating all these phenomena (Neményi [25]). More briefly stated, the cause of the underprivileged status is the result of the segregating characteristics of the school-system, the discriminative practices of the employers and the prejudices of society.

\section{Solving the 'Malay Problem' in Singapore since the 1960s}

Figure 1 shows Malays' improvement in education and occupation between 1980 and 2005. We must add that this improvement is not only the consequence of the achievement gap closing efforts but also the overall development of the Singaporean economy and the well-thought-out and implemented economic policy strategy. Unemployment in Singapore has been very low (under 3\%) since the beginning of the 1980s with the exception of a five-year crisis period at the beginning of the 1980s when unemployment was between 9 and $13.5 \%$. Singapore males (aged 25 to 64) have among the highest employment rate internationally ( 86 to $89 \%$ between 2006 and 2008), and total activity rate is also very high (consistently increased from $58 \%$ in the 1980 s to $75 \%$ in 2008) (source: Singapore Statistics). The education policy was systematically planned to meet the labour demand, while the social benefit system is a state managed, fully funded, defined contribution (DC) system with very small redistribution effects that benefits the poor and the inactive ${ }^{2}$. The fertility rate was forced down by strict economic measures as the Stop at Two programme promoted two-children families and sterilisation (primarily targeting low-educated and low-income women with high economic incentives) since the late $1960 \mathrm{~s}$ Since 1987, however, the anti-natalist policy was replaced by the pro-natalist Have Three or More (if you can afford it) policy.

As both Malay leaders and government representatives considered education as the key factor in the problem-solving process, they first focused on the educational problems (Kassim [14]), i.e. the widening achievement gap between the Malay and non-Malay students, the low performance in core subjects - English, mathematics and science - the overrepresentation of

\footnotetext{
${ }^{2}$ Singapore's social benefit system is based on the Central Provident Fund (CPF), which was established in 1955 by the British administration.
} 


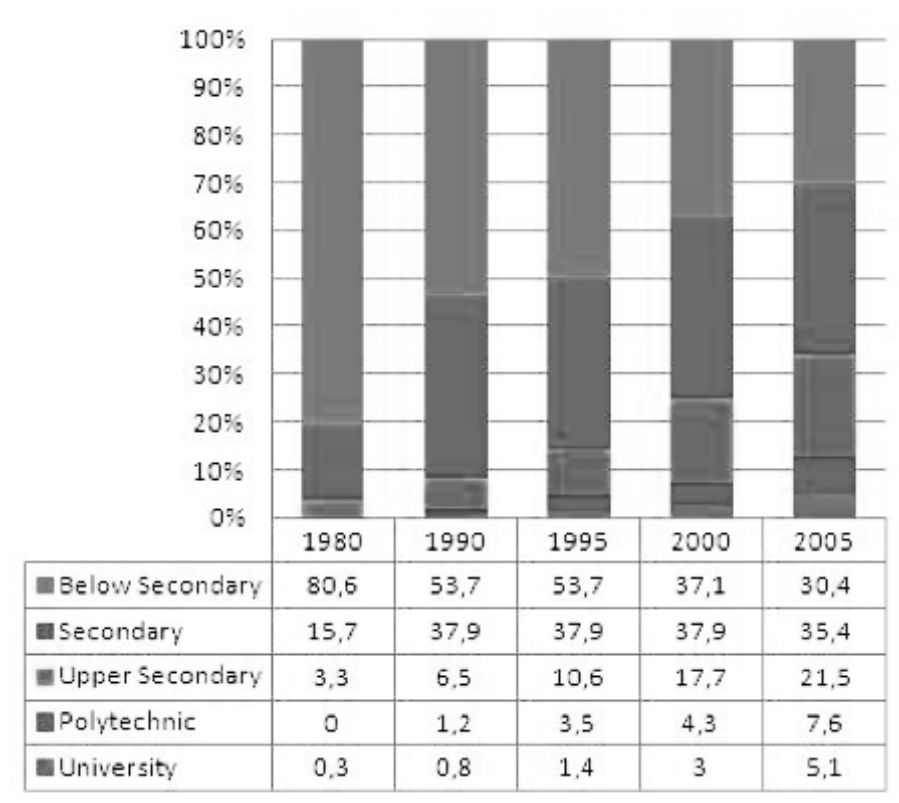

\begin{tabular}{|c|c|c|c|c|c|}
\hline \multicolumn{6}{|l|}{$100 \%$} \\
\hline $90 \%$ & & & & & \\
\hline $80 \%$ & & & & & \\
\hline $70 \%$ & & & & & \\
\hline $60 \%$ & & & & & \\
\hline $50 \%$ & & & & & \\
\hline $40 \%$ & & & & & \\
\hline $30 \%$ & & & & & \\
\hline $20 \%$ & & & & & \\
\hline $10 \%$ & & & & & \\
\hline $0 \%$ & 1980 & 1990 & 1995 & 2000 & 2005 \\
\hline Others & 3,8 & 3 & 3,8 & 2,3 & 3 \\
\hline In Cleaners \& Labourers & 20,2 & 16,2 & 13,6 & 10,7 & 10,8 \\
\hline =Procuction \& Related & 45,1 & 37,7 & 30,4 & 27,5 & 26,1 \\
\hline Sales \& Services & 13,6 & 15,4 & 14,9 & 16,2 & 20,3 \\
\hline aclerical & 10,2 & 16 & 18,9 & 20 & 18,6 \\
\hline -Technical \& Related & 4,6 & 8,4 & 13,9 & 16,4 & 14,2 \\
\hline Professional & 1,9 & 2,2 & 2,9 & 4,1 & 4,6 \\
\hline $\begin{array}{c}\text { Administrative } \& \\
\text { Managerial }\end{array}$ & 0,7 & 1,1 & 1,6 & 2,9 & 2,4 \\
\hline
\end{tabular}

Fig. 1. Occupational distribution of Malay working persons (aged 15 and over) (\%) Source: Progress of Malay community in Singapore since 1980 [29]

Malay students in weaker stream $\unlhd^{3}$ the non-sustained educational progress among Malays, the high attrition rate among Malays, and the few Malays in tertiary education.

Figure 2 shows the narrowing of the achievement gap in education among Singaporean minorities between 1990 and 2005. Figures 1 and 2 indicate why it is worth examining the problemsolving process in Singapore.

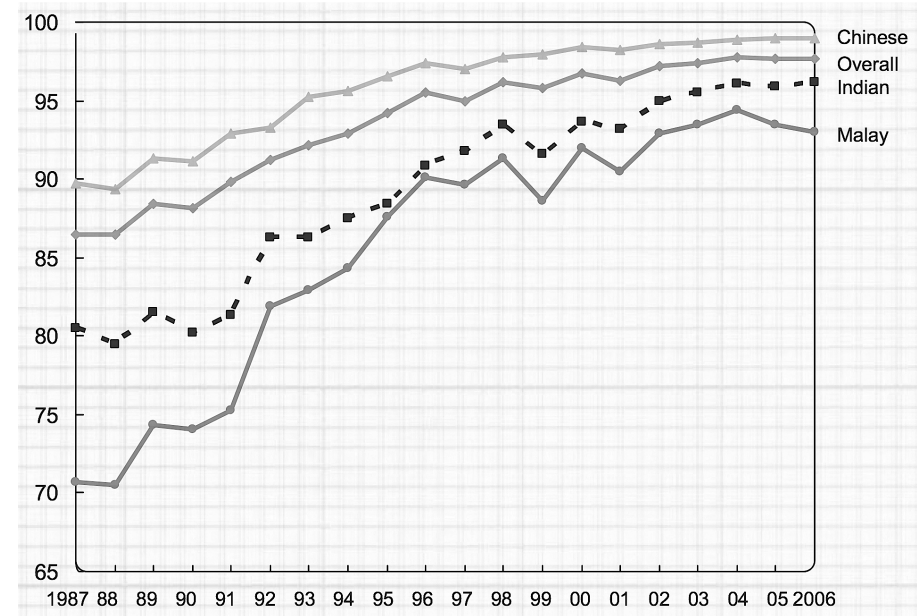

Fig. 2. The percentage of pupils who sat for the primary school leaving exam and achieved eligibility for secondary school by ethnic group Source: Mckinsey (2010)

Several explanations have emerged to unravel the root causes of the problem. There are those that explain the problem only with historical facts (British colonial deprivation) and those that

\footnotetext{
3 The Singapore education system is based on the principle of meritocracy. Since the mid-1980s, students are streamed into different classes based on their test results at the end of the fourth school year (For more information: WWW.moe.gov.sg
}

blame the Islamic religion, but most Malay leaders, members of parliament and researchers accept that the most important and only reversible root cause is that Malay parents do not motivate their children at home, do not have expectations of their children and are not involved in their children's education ${ }^{4}$ (Kassim [14. p. 47]). Accordingly, Malay leaders began to espouse that the problem can only be solved by changing attitudes (Kassim [14. p. 48]).

\subsection{The beginnings (1959-1980)}

The People Action's Party (PAP) was elected in Singapore in 1959 and has remained in power since that time. It was then that the government began to positively discriminate the Malay aboriginals, and the Malay language was chosen as one of the official languages of Singapore and remains so to this day (Ministry of Education 1962 [22]; Zahoor [42]). The problems of Malays quickly became evident in every field, including education, employment, and living standards. To solve this problem, the government established pro-Malay policies such as providing the Malays with bursaries as well as free secondary and tertiary education (Ministry of Education 1962 [22]; Zahoor [42]).

After becoming fully independent in 1965, the city-state began a new era in minority policy, and Equality became the guiding principle. This was the beginning of meritocracy ${ }^{5}$ and the

\footnotetext{
${ }^{4}$ Many studies in the field of social-pedagogy came to the same conclusion, i.e., those students whose parents actively take part in their lives (achievement expectations, help at home, participating in school events, consulting with teachers, etc.) perform better than students who are not motivated in this way (Parental Involvement in Schools [28]).

${ }^{5}$ Meritocracy, in the most administrative sense, is a system of government or other administration (such as business administration) wherein appointments
} 
positive discrimination of Malays as aboriginals ceased. The Islamic Religious Council of Singapore (MUIS), the governmental body for Islamic affairs, was then established in 1968 to address the welfare and religious concerns of Muslims, among others (Website of the MUIS [54]).

However, while various Malay organisations and leaders were continuously requesting the government's participation in solving their problems (Kassim [14]), none of these attempts had an effect on minority policies. Accordingly, the Malays realised that they had to find their own solutions (Kassim [14, p. 40]).

This was the point when Malay leaders began to apply the concept of self-help in Singapore. This means that Malay politicians and community leaders established self-help organisations, with some indirect governmental help, to combat the Malay communities' internal inertia (Tan [40, pp. 9-10], Kas$\operatorname{sim}$ [14, p. 89]).

The efforts, in the beginning, were uncoordinated because each organisation and group began to work independent of the others. The most widespread view was that the 'Malay problem' could be solved with financial support and through education that incorporated extra curricular activities. Focused on this theory, Malay leaders implemented short-term plans (Kassim [14]).

\section{Streaming}

As emphasis was placed on education to solve the Malay problem from the very beginning, it is important to note the related developments of the Singaporean education system. The Singaporean education system reached its next level of development in 1979 with the introduction of the 'New Education System'. One of the most important steps was the introduction of streaming in 1984. Streaming essentially ranks students after the fourth year of school into more homogeneous classes based on the students' skills and abilities (Website of National Library Singapore [24]; Gopinathan-Ho [10]). It was clear that with this new system, the majority of Malay students were being streamed into the weaker academic courses. In the beginning, there was almost no pervasion between the streams, and as a consequence, Malay pupils' academic progress was essentially pre-determined (Kassim [14, p. 20]).However, since the launch of streaming, the educational system has changed significantly, and today, it is easier to move from one stream to another (Secondary School Education Booklet [33]). For example, $15 \%$ of Malay students achieved secondary express, $30 \%$

and responsibilities are objectively assigned to individuals based upon their 'merits', namely, intelligence, credentials, and education, as determined through evaluations or examinations (Young, Michael, 1958, The rise of the meritocracy, 1870-2033: An essay on education and inequality. London: Thames \& Hudson. OCLC 3943639).

${ }^{6}$ Malays are mostly Muslims in their religion. 'The role of MUIS is to see that the many and varied interests of Singapore's Muslim community are looked after. In this regard, MUIS is responsible for the promotion of religious, social, educational, economic and cultural activities in accordance with the principles and traditions of Islam as enshrined in the Holy Quran and Sunnah' (Website of the MUIS [54|) attained normal academic level and 50\% progressed to normal technical level in 2004 (Kobayashi [18]). Based on the McKinsey Co.'s findings, streaming and specially designed curricula helped the less capable students to successfully pass the Primary School Leaving Exam (PLSE) and continue their studies at secondary level, allowing them to attain a General Certificate of Education at the Ordinary level (GCE O-level) (McKinsey \& Company 2010) (See Figure 2).

In conclusion, after the seminar in 1971, the next 10 years showed noticeable development; however, based on the 1980 census, the results were still far from the expected achievements (Tan [40]; Kassim [14]), and it became clear that the problem could not be solved by targeting only the pupils, as the programmes that were launched to change the attitudes within the Malay community were without significant effects until 1980 even though more and more politicians and researchers emphasised the importance of addressing the entire Malay community, i.e., not only pupils (Kassim [14]).As a result, Malay members of parliament and the already existing Malay organisations' leaders established, in October 1981, the 'Council on Education for Muslim Children' (briefly called Mendaki 7 ). This was the first umbrella organisation whose main scope was to enhance the education of the whole Malay community beginning with primary school and concluding with various academic research activity that could help to narrow the achievement gap (Tan [40, p. 9]).

Throughout the 1980s, the government's attitude also changed from one of denial and refusal to one of support (Tan [40, p. 14]).Self-help organisations began to emerge on a voluntary basis, and initially, most were independent from the government, but as Singapore civil organisations faced a high level of political control (Ooi [27]), as a matter of course, the government became involved in both voluntary and nongovernmental organisations (Juhari [13, p. 166]).Lee Kuan Yew, the Prime Minister at that time, highlighted in his speech that 'a government-run scheme cannot achieve a quarter of the results of these voluntary, spontaneous efforts by the Malays/Muslims to help themselves' (Lee [19]).

As the current educational attainment of Roma in Hungary ${ }^{8}$ (BCE, 2011) is similar to that of the mid-1980s in Singapore (see Figure 1), the most important factor to examine is the achievement gap closing efforts in Singapore since 1980.

\subsection{The problem-solving process from the beginning of the 1980s}

We introduce the organisational build up, the programmes and the current financing of Malay achievement gap closing efforts in Singapore in the following subsections ${ }^{9}$

\footnotetext{
7 The abbreviation comes from the Malay name of the organisation, that is, 'Majlis Pendidikan Anak-Anak Islam'.

${ }^{8}$ Figure on Roma educational attainment statistics is available upon request

${ }^{9}$ Figure on the structure of Malay self-help organisations and programmes in Singapore is available upon request
} 


\subsubsection{Organisational build up}

\section{Mendaki}

The already mentioned Mendaki was established with the participation of the nine Malay members of parliament (MP). Initially, the primary focus was on education (Juhari [13]), and Mendaki's role was to act as a 'social catalyst' for creating a new attitude in Muslim homes and in the majority of the society. Accordingly, Mendaki focused not only on religious education but also on academic curricula as well (Tan [40, pp. 9-10]).

The response of the community was not positive due to lingering doubts regarding the government's aims about supporting the organisation. After the initial difficulties, however, the Mendaki programme had much more greater effects on Malay's development than all other measures implemented by the government thus far. The most important programme within Mendaki is the educational programme, which started in 1982. Called the 'Mendaki Tuition Scheme', it was developed in parallel with the educational system and was converted to meet the requirements of the changing educational system (Webpage of Mendaki [48]). Acknowledging Mendaki's successes, the government encouraged the organisation to broaden its scope (Tan [40, pp. 910]), and as a result of this expansion, Mendaki took over more functions that had previously belonged to the government (Juhari [13]). The Ministry of Education and the Mendaki established the Mendaki-Ministry Joint Committee (MMJC) in 1989, an organisation whose primary scope was to improve the results of Malay students by focusing on school-based and communitybased programmes (Kassim [14, p. 94]).

While the organisation had launched a wide range of projects, it maintained its main focus on educational problems targeting the achievement gap. Accordingly, in addition to scholarships, study loans, and remedial and supplementary lessons, the committee launched programmes to facilitate the involvement of parents and the whole family (Kassim [14, p. 101]).

Over the years, the organisation played an even more significant role by drawing attention to the importance of changing attitudes towards the education of Malay children. Sometimes even the Ministry of Education helped to organise and promulgate these programmes, and more than 80 schools were involved in one way or another in the promotion of Malay education (Kas$\operatorname{sim}$ [14, p. 95]).

\section{Mendaki SENSE}

Mendaki's subsidiary, the 'Mendaki Social Enterprise Network Singapore Pte Ltd' (briefly referred to as Mendaki SENSE), provides trainings, re-trainings, and educational services to improve employability. It also collaborates with the Singapore Workforce Development Agency to connect workers and families with programmes that allow them to return to employment. Mendaki SENSE's main scope is to support those who were affected by structural changes in the economy, with the aim to help strengthen the community's economic resilience. In addition to these tasks, Mendaki SENSE provides counselling services and job matching assistance (Webpage of Mendaki-SENSE [50]).

\section{Mendaki Club}

Mendaki Club is an affiliate institution of Mendaki, which separated from the main body of the organisation in 2000 . It is made up of Malay/Muslim students and young professionals who work in a variety of fields. These youths are committed to upgrading their community and creating an understanding and collaborative atmosphere throughout Singapore. Their main activities include the remedial and tuition classes that target high school students, support individual talent and motivate students by being an example for them through their activities. Additionally, the club organises various seminars and forums about relevant topics and promotes various series of events that create platforms for the Malay/Muslim youths and professionals (Juhari [13, p. 152]).

\section{AMP}

The Malays/Muslims organised other self-help, nongovernmental-organisations as well, for example, the Association of Muslim Professionals (AMP), which was established in 1991. The AMP started its activities without government involvement. Initially, it was a competitor for Mendaki, while also providing opportunities for those who did not wish to participate in a government led organisation. In 2001, the AMP agreed with the government to form a collective leadership comprised of Malay MPs from the People's Action Party and Malay leaders elected only by Malays to maintain the non-political pillar of the organisation (Kassim [14]).

The AMP's programmes were extended to encompass a wider range that consisted of various types of educational, social and workforce development programmes managed and executed by the self-help group from the early beginnings of the organisation. While Mendaki was developing its programmes gradually, AMP started its operation with a holistic approach from the start (Juhari [13]).

\section{Young AMP}

AMP has a youth organisation called the Young AMP, which was established in 2004. Its scope is to improve the Muslim community's academic achievements, cultural activities, political influence, religious profundity and economic dynamism (Young AMP 2009). Their vision is to establish a community that is able to think, act, and reflect critically. Young AMP targets Malay/Muslim youths between the ages of 17 to 19 and challenges them to lay the foundations of Malay/Muslim professionals and leaders (Juhari [13, p. 176]).

\section{Clubilya, Ain Society}

It is important to mention two other Malay non-profit selfhelp organisations as well, the Ain Society, established in 2000, and the Clubilya, established in 2004. Both organisations play 
crucial roles in helping the out-of-school, at-risk and/or disadvantaged youths and offer family welfare services. They organise activities with the aim to reinstate children to schools and to equip them with social skills, vocational training and other knowledge, such as IT knowledge, while also providing welfare services. Members of Clubilya are professionals with experience in the field of family service, law enforcement, rehabilitation and the judiciary and they have the knowledge and skills required to address at-risk youth (Juhari [13, p. 162]).

\section{PMBM}

There are many other initiatives designed to solve the Malay problem. Among them is the welfare organisation's scholarship competition, 'The Prophet Muhammad's Birthday Memorial Scholarship Fund Board (PMBM)'. This specifically targets university students and challenges them to analyse the 'Malay problem' and present proposals for solving the problem. The winner of the competition receives a cash prize of $3000 \mathrm{~S} \$$ (Suhaimi [39]).

\subsubsection{Programme build up}

From the beginning, each organisation based its activities on programmes that targeted students, but they soon realised that these types of programmes do not necessarily lead to the results expected and that the achievement of students does not depend only on educational programmes and school activities. Therefore, they continued to search for other solutions to address the problem (Kassim [14]).

After a long trial period, the current programmes can be categorised as follows (Mendaki Annual Report [21]): 1. Strengthening partnerships and relationships, 2. Youth programmes, 3. Family programmes, 4. Programmes for employability, 5. Education programmes, 6. Scholarships, and 7. Enhance research capability.

The programmes are clustered along five strategic areas: education, youth, family, employment, and research capability. Housing could be the sixth, but housing was addressed by establishing the Housing Development Board in the beginning of the 1960s. The government eliminated ghetto settlements and implemented an ambitious desegregation strategy by mixing the population into public housing estates. It is important to mention that each citizen had to buy his/her own house, a goal which was affordable because each citizen had their own CPF savings. The various community organisations played an important role in easing the tensions between different races. To sum up the importance of the public housing project, "if the government were to leave it to market forces, and not introduce some measure of control through its allocation policy and related measures, it will not be possible to achieve social integration as ethnic groups have a tendency to cluster as shown in cities elsewhere' (Boal [4], Dunn [7], Smith [37], Blainey [3] in Sim et al. [36]).
The following section introduces the programmes according to the aforementioned fields. Our aim is to offer a holistic view on the programmes and to mention the most important ones.

\section{Strengthening partnerships and relationships}

In Singapore's multi-ethnic and multi-religious society, the self-help groups, namely, the Chinese Development Assistance Council, the Eurasian Association, the Singapore Indian Development Association and Mendaki, play an important role in helping to ensure that every Singaporean is able to keep pace with the changes in our operating environment and benefit from the economic progress of the country' (Mendaki Annual Report [21]). Programmes to strengthen partnerships and relationships are based on collaborations between various organisations, groups and institutions that include all races (Mendaki Annual Report [21]).

'As a pioneer self-help group, Mendaki has, over the years, collaborated with the other SHGs in many fields providing assistance in education, employment and youth development. Through joint projects such as the Collaborative Tuition Programme, the Bridging Programme, Community Tuition Fee Subsidy Scheme and Joint Job Fair, the SHGs helped to bring the government programmes and assistance schemes closer to the respective communities and help to build trust, confidence, tolerance and mutual respect between the different communities' (Mendaki Annual Report [21]).

Different races effectively work together through these collaborative programmes and share their experiences, information and knowledge. In this way, they invest not just in their own communities, but in programmes where they create and reinforce partnerships with people of different cultures and backgrounds (Mendaki Annual Report [21]).

In today's society, Mendaki is considered the most important and most extensive Malay/Muslim organisation that collaborates with other organisations.

In the field of strengthening partnerships and relationships not only were programmes for education, youth, employability, family, and enhancing research capability launched but programmes that are linked closely to strengthen partnerships were also established, such as the National Orange Ribbon Celebration to celebrate racial harmony (Mendaki Annual Report [21]). Regardless of their type, if the projects are jointly organised with other organisations in the field of self-help activities, they are included among the strengthening partnership and relationship programmes (Mendaki Annual Report [21]).

An important collaboration is the initiative of the Muslim Religious Council (MUIS) and the Mendaki. During the Friday sermons, religious leaders highlight the importance of education in shaping Muslims attitude, providing them with the correct interpretation of religious values and helping them to create a new context of religion (Website of MUIS [52]).

The conviction on the importance of these partnerships has spread, and a wide network of society members, organisations 
and governmental institutions now exist to support disadvantaged members of the society regardless of their racial background.

\section{Youth Programmes}

Youth programmes have three main pillars: rehabilitation, prevention, and empowerment and integration. Among these, the greatest challenge is rehabilitation.

The aim of the rehabilitation programmes is to re-integrate and assist the out-of-school students and prevent the youths who are on the brink of success from quitting school. For example, Clubilya collaborates with the specialised crime expert branch of the Singapore police, which pre-selects youths to the 'Giant Trampoline Project'. Those who already have had some issues with the police are selected to participate in the programmes to motivate them to become useful individuals of society through various activities, courses and professional help organisations (Juhari [13, p. 163]).

Prevention programmes consist of preventive and developmental programmes designed primarily for teenagers. Their role is to introduce the problems to the students as early as elementary school and help them understand the consequences and importance of their decisions and the value of education and studying. The Clubilya's programme, 'Project Reach' is a good example. Another programme, specifically for girls, is the 'Juz Gurlz', which targets girls between the ages of 10 and 14 with the aim to empower and inspire them to develop their vision during these early years and to be strong and smart (Juhari [13, p. 179]).

There are additional programmes that target secondary school students, especially those students who are in weaker streams. The programmes for these students provide activitybased studying that is based on workshops and group-work (Juhari [13, p. 164]).

Values such as empowerment and integration are the focus of the two youth organisations, the Mendaki Club and the AMP Young, which work to promote Muslim/Malay youth development both at the personal and the professional level (Website of Mendaki Club [49]).

\section{Family Programmes}

Mendaki has long regarded parental involvement in education as a high priority because parents can motivate their children through parental expectations and encouragement. However, most Malay parents did not find these values to be important, and they lacked the capabilities to help their children. The self-help organisations tried to change these negative attitudes among the Malay/Muslim families through various programmes.

One group of programmes is designed to prevent the formation of dysfunctional families. The government organised prevention and care programmes and offered pre-marital courses with the aim of providing help and information for youth to make deliberate and informed decisions on marriage (Building Resilient Family Institutions [5]).

Another group of programmes have been focused on the parental role in school results since 1982. In 1987, Mendaki formed the 'Child and Family Development Department', which organised numerous educational programmes (A-Plus, ActionParent Learning Useful Strategies, Early Childhood and Family Education Programme, etc.). All of these programmes were designed to provide parents and prospective parents with the skills necessary to effectively raise children. Nevertheless, the most important factor was promoting the right attitude towards education (Kassim [14, p. 95]).

The third group of programmes relating to the role of parents was the need for parents to help their children study at home. Some researchers claim that the daily help provided by the parents and the parents' expectations of their children could be the answer to improving academic achievement and narrowing the gap. Based on a comparison of the results, Malay students are weaker in mathematics and science, areas in which practice at home could help them to achieve higher scores. However, as many parents had low educational attainment themselves, they are unable to help their children even at the elementary level. To solve the problem, Malay/Muslim organisations launched programmes to prepare parents in mathematics while also concentrating on reading and writing skills. For example, in 1991, AMP initiated a programme that was obligatory for parents whose children started the AMP's pre-school programme (Kassim [14, pp. 89-93]).

Another example worth mentioning is Mendaki's 'Exam Ready Campaign' of 2003 that prepares parents to support their children who are preparing them for the elementary final exams. During the campaign, seminars were held and exam kits were given to disadvantaged Malay families. That programme was so successful that parents asked for these types of programmes during the school-year as well (Sen [34]).

\section{Programmes for Employability}

Programmes for employability became an essential part of the problem-solving process. The already mentioned Mendaki SENSE is the most important Malay/Muslim organisation in this field with an exclusive range of programmes, including counselling, career service, and most importantly, courses providing skill development, training and re-training.

Mendaki SENSE and the national productivity board jointly organised courses for Malay/Muslim workers who did not complete elementary school. There is a special express programme for these workers, beginning with the 4th grade and based on providing basic knowledge in mathematics (Kassim [14, p. 96]).

One of the most often stated criticisms is that Malays are less active economically, and they lack an entrepreneurial spirit. This is the reason for the introduction of the micro business programme, which helps low-income families start their own businesses. The programme has various phases, such as orientation 
and career coaching, and it offers business and IT courses for the participants (Webpage of AMP [45]).

Mendaki SENSE also offers trainings and re-trainings, working closely with government agencies to match the supply and demand (Webpage of the Mendaki SENSE [50]).

\section{Educational Programmes}

Educational programmes remain among the core activities of the problem-solving process, and these programmes are the focus of each organisation (Kassim [14]).

The substance of these programmes is to reduce the achievement gap between Malay, Chinese and Indian students by helping students and preparing them for the exams, especially in the most important subjects (Kassim [14]).

Among the programmes, Mendaki launched remedial afternoon and weekend classes and home tuition classes, such as Mendaki tuition scheme or weekend tuition scheme, which started in the 1990s. Meanwhile, programmes were spreading in the community, and the variety of subjects was expanding. Initially, Mendaki focused only on mathematics and English, as core subjects in the education system, but later, it began to include other subjects as well (Kassim [14, p. 96]).

Another remarkable initiative is AMP's 'Mathematics @ Home Learning Kit', a pack of exercises and tools focused on certain mathematical topics. The kit was developed after research conducted by AMP (Kassim [14, p. 101]).

Apart from factual knowledge, Mendaki also focused on motivation and encouragement as essential to the success of promoting academic achievement. Accordingly, it organised workshops for new students to motivate them to be excellent students, and it offered professional help for secondary school students and introduced them to efficient study methods. It also implemented a programme called 'Big Brother Scheme', the aim of which was to encourage the best students, those who performed among the best $10 \%$ of their cohort on the primary school leaving exam (PSLE), to be mentored by businessmen and professionals who helped them to maintain academic excellence in secondary school (Kassim [14, p. 94]).

\section{Scholarships and financial support}

Because of its meritocratic educational system, there are many types of scholarships and bursaries in Singapore, not only for disadvantaged students, but for those who excel in education as well. There are also a number of study loans and other financial instruments for disadvantaged students that allow them to continue their education without financial difficulties. These financial instruments are offered by the state or by organisations and self-help groups. To be awarded any kind of financial support, each candidate must match many requirements (e.g., net monthly income per capita). In many cases, students from lower-income families have better opportunities to obtain school result-based financial support, such as support from the spe- cial Malay bursary managed by Mendaki (Webpage of the Mendaki [48]).

The 'Ready for School Fund', launched by AMP in 2002, helps disadvantaged students with tuition fees and other education-related costs (AMP website [46]), while the Ain Society offers a similar programme to help low-income students meet the financial requirements of education (Website of Ain Society $[44])$.

\section{Enhance research capability}

It is essential to conduct detailed research and to monitor and analyse programmes to develop new ones. There are more research centres that monitor and analyse programmes and create policy-proposals on education, religion, as well as other topics. There are two main research centres, one within Mendaki and the other that operates as a subsidiary of AMP. The 'Centre for Research on Islamic and Malay Affairs' (RIMA) was a subdivision of AMP in the beginning, but in 1998, it became a subsidiary as its importance and its number of tasks had increased. As of today, it serves not only the interest of the Malay/Muslim community but the interest of the entire country (Webpage of Rima [51]).

\subsection{Financing}

Financing was a significant challenge in the beginning, but with the introduction of two voluntary contribution schemes, financing became less problematic. However, it is still difficult to provide financial continuity. At times even the government or volunteer agencies provided contributions. This dependence on irregular contributors was also one of the reasons for the failure of the early programmes (Tan [40, pp. 10-11]; Rasheed [31, p. 9]).

In 1984, an existing fund, the Mosque Building Fund, was expanded to become the 'Mosque Building and Mendaki Fund' (MBMF) with the aim to support programmes of Mendaki (MBMF [20]). The fund is run through the Central Provident Fund and managed by the MUIS. The contribution is compulsory for each Muslim worker on the basis of their monthly income (About MBMF [1]; MBMF [20]). Table 1] shows the CPF contribution rates to MBMF.

Tab. 1. Compulsory contribution rates for the Mosque Building \& Mendaki Fund and the distribution of the funds. Source: Latest Monthly MBMF Contribution Rates (2011)

\begin{tabular}{|c|r|r|r|}
\cline { 2 - 4 } $\begin{array}{c}\text { Total monthly } \\
\text { wage (SS) }\end{array}$ & $\begin{array}{c}\text { Total } \\
\text { monthly } \\
\text { contribution } \\
\text { (SS) }\end{array}$ & $\begin{array}{c}\text { Mosque building } \\
\text { \& religious } \\
\text { education } \\
\text { component (S\$) }\end{array}$ & $\begin{array}{c}\text { Mendaki } \\
\text { component } \\
\text { (S\$) }\end{array}$ \\
\hline 1000 S\$ and below & 2 & 1 & 1 \\
\hline $1001-2000$ S\$ & 3,5 & 2,25 & 1,25 \\
\hline $2001-3000$ S\$ & 5 & 3,6 & 1,4 \\
\hline $3001-4000$ S\$ & 12,5 & 8 & 4,5 \\
\hline Above 4000 S\$ & 16 & 10,75 & 5,25 \\
\hline
\end{tabular}

Another fund managed by the MUIS is the Scholarship and Education Fund, which was established in 1998 with the aim to 
Tab. 2. Costs of the Mendaki programmes by types, 2009. Source: Mendaki Annual Report [21] (*Support costs are allocated to charitable activities based on the level of activities.)

\begin{tabular}{|c|c|c|c|c|c|c|c|c|}
\hline Costs by Program Types (S\$) & Youth & Family & Employability & Education & Scholarship & $\begin{array}{l}\text { Enhance } \\
\text { research } \\
\text { capability }\end{array}$ & $\begin{array}{l}\text { Strenghtening } \\
\text { partnership and } \\
\text { relationship }\end{array}$ & Total \\
\hline Costs of Activities (S\$) & 1352890 & 1665601 & 5885991 & 357576 & 6629749 & 786709 & 18605668 & 35284184 \\
\hline $\begin{array}{l}\text { Support Costs* (S\$) } \\
\text { (administration, human resources) }\end{array}$ & 202930 & 183670 & 479697 & 700173 & $\cdot$ & 121446 & 275887 & 1963803 \\
\hline Total (S\$) & 1555820 & 1849271 & 6365688 & 1057749 & 6629749 & 908155 & 18881555 & 37247987 \\
\hline Percentage of Total cost & $4 \%$ & $5 \%$ & $17 \%$ & $3 \%$ & $18 \%$ & $2 \%$ & $51 \%$ & \\
\hline
\end{tabular}

provide scholarships to Muslim students pursuing their studies at the graduate and post-graduate levels. Since the formation of the fund, only S\$3 027319 has been expended from the total S\$11 731231 (MUIS Annual Report 2010 [23, p. 131]).

Both the compulsory and the voluntary contributions are collected by the MUIS in the CPF system. Even the state contributions are managed and distributed through the CPF. The MUIS has an account for the Mosque Building and Mendaki Fund, whereby payments are charged separately (MUIS Annual Report 2010 [23, pp. 125-127, 30-40]).

After having an idea about the structure of contributions and the management of Mendaki's resources, it is worth examining how the resources are spent. As the major part of the welfare and charity programmes are organised by Mendaki, the analysis of resource distribution within the Mendaki programmes provides a good estimate on the amount spent annually on the achievement gap closing efforts (Tab.2).

It is noticeable that more than the half of the resources were spent on partnership and relationship strengthening programmes. This emphasises the importance of the collaboration of various nationalities, the sharing of experiences and the bestpractices in each relevant field, such as the field of education, youth, families, employability and research. It is relevant to maintain the close relationships and to launch programmes that have already proven to be efficient.

It is worth comparing the total costs to see how much Singapore and Hungary spend on achievement gap closing and integration effort programmes,

The latest and most reliable data for estimation are for the year 2006 in Hungary and 2009 in Singapore. We compare annual spending to the percentage of GDP. Hungarian efforts were futile between 1996 and 2006, while Hungary spent 120 billion in those 10 years (Pulay-Benkő [31]), which was approximately $0.05 \%$ of its annual GDP, while Singapore spent approximately $0.013 \%$ of its annual GDP.

\section{Conclusions}

There are several different but correlating conclusions that can be drawn from the process of solving the 'Malay problem' in Singapore. Accordingly, however, we must also mention the specific differences between the two challenges (i.e., 'Malay problem' and 'Roma issue') to make the comparison more valuable.

1 Naming the problem by minority leaders. The essential part of the problem- solving process began in 1971 when Malays and Malay leaders acknowledged and declared the existence of the so-called 'Malay problem'. Named the most important symptoms, work was begun on changing the attitude in their communities.

2 Focus on education and changing attitude. A focus was initially placed on education, but since the 1980s, after evaluating the results of the educational programmes, more emphasis was placed on attitude-changing programmes and programmes designed to address the whole family.

\section{Strengthening partnership and relationship programmes} constitute $51 \%$ of the total achievement gap closing budget in Singapore. This means that emphasis is placed on joint programmes of different nations and different organisations. It also shows that this problem is multi-racial in composition, and Singapore handles it as an economic problem rather than as a minority issue. However, data collection on minorities shows that some minorities are affected by this problem to a greater extent than others.

4 Data collection and monitoring of minorities. It is essential to collect data on minorities to be able to measure and evaluate the effectiveness and efficiency of the programmes. Thus, data collection on minorities' school results, employment, living circumstances and other factors is inevitable.

5 Internal financing. The Malay achievement gap closing efforts were and are primarily financed from Malay sources, which is part of the change in attitude. As a consequence, Malays appreciate and protect the results much more than if they were financed from outer sources.

\section{Major differences:}

1 The extremely low employment rate of Malays has never been a problem in Singapore, though it has been a major problem for Roma in Hungary. The social benefit system has never been as generous in Singapore since the 1960s as it is in Hungary, thus the differences in the weights of employment 
Fig. 3. Action Plan 2012-14 budgets by categories (authors' contribution)

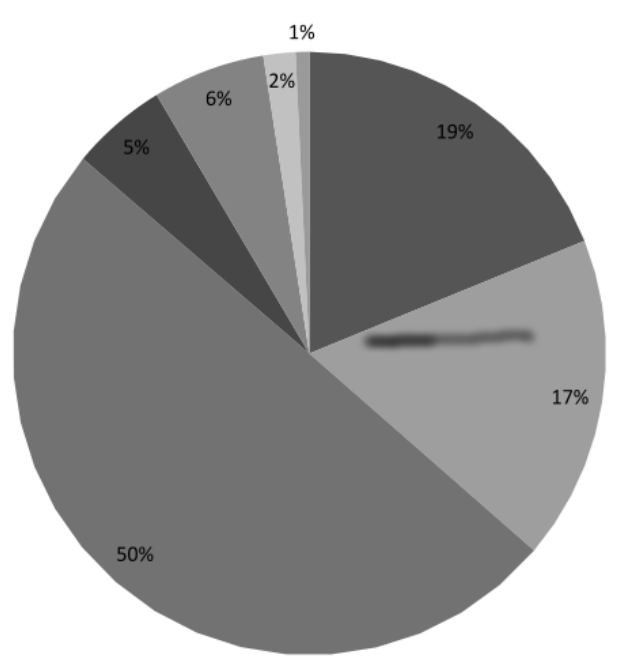

I. Child welfare

=II. Education

- III. Employment and training

IV. Health

V. Housing

VI. Involvement, change in attitude (shaping worldview), and public securitiy programs

= VII. Strategic coordination programmes among the achievement gap closing programmes are explainable by this factor.

2 Housing was handled in Singapore as a national rather than as a minority issue. Housing was an important part in integrating the different minorities in Singapore, but it does not belong to conventional achievement gap-closing efforts in Singapore. Housing was not free as each citizen, regardless of nationality, had to pay for better housing conditions.

The problem solving in Singapore is based on a holistic approach that recognises both the external elements (segregation, discrimination and exclusion) as the root cause of Malays' underprivileged status and the internal inertia of the Malay community (impedimental attitudes and separation) as another root cause. This approach can be described by the double-loopedvicious-circle concept as displayed in Figure 4(György [12]).

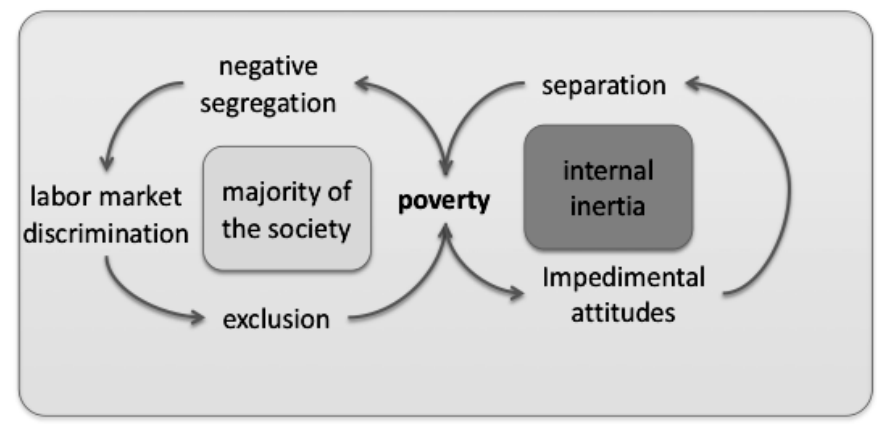

Fig. 4. The double-looped-vicious-circle hindering underprivileged minorities Source: György [12]

The Hungarian Action Plan 2012-14 contains 7 programme categories and 51 sub-categories among which the 200-240 billion HUF (0.7-0.85\% of GDP) - mostly EU funded - tenders are planned to be distributed. Figure 3 shows the planned distribution of resources.

As evident in Figure 3, the tenders correlated with employment and training represent the greatest $(50 \%)$ portion of the total budget. This is inevitable in view of the Roma employ- ment and educational attainment statistic 10 combined with the 2012 changes in the Hungarian social benefit system, which now favour active versus inactive status.

The major difference in the Hungarian plans and the realised efforts in Singapore is the focus of the programmes (A detailed description of the Hungarian Action Plan is available upon request or see Action Plan 2012-14 [2]). The Singapore model delegates responsibility to and requires an active participation from Malays in their overall (education, living standard, employment etc.) closing-up and places a tremendous emphasis on changing attitudes, while the Hungarian model regards the Roma minority rather as a passive 'participant' or 'endurer' of the whole close-up process. There are only two sub-programme points that address the change in attitude of Roma, and both have negligible budget plans (sub-programme point no. VI. 4. and 12. in Action Plan 2012-14 [2]). A much larger emphasis should be placed on Roma involvement and the change in attitude.

Our intention was to present the degree to which a change in attitude can improve results of underprivileged groups in a very cost effective way. It is important to stress that the achievement gap narrowed in Singapore as a result of the improvements in the Malay communities only, not due to the fallback of other communities. Furthermore, the gap not only narrowed but also moved upward, thus benefiting all ethnic groups in Singapore due to the policies presented in this study.

\section{References}

1 About MBMF, 2012-04-19, http://wWW.muis.gov.sg/cms/services/m bmf_subpg.aspx?id=560

2 Akcióterv 2012-14: A Kormány határozata a Nemzeti Társadalmi Felzárkózási Stratégiáról, valamint végrehajtásának a 2012-2014. évekre szóló kormányzati intézkedési tervéról (Government Resolution on the National Achievement Gap Closing Strategy and on its implementation plan between 2012 and 2014), 2011.

3 Blainey G, Australia must break down the walls of the Ghettos, The Weekend Australian, (March 12-13, 1988), 18

\footnotetext{
10 There is a $40 \%$ gap in Roma/non Roma employment (Kertesi-Kézdi [16]). Detailled Roma employment statistics are available upon request.
} 
4 Boal F (ed.), Ethnicity and housing: Accommodating the differences, England: Ashgate, 2000.

5 Building Resilient Family Institutions, REACH, 2005, www.reach.gov. Sg

6 Singapore Department of Statistics, Census of Population 2010, 2011, cited 2012-03-27, http://wWw.singstat.gov.sg/pubn/popn/c2010a cr.pdf

7 Dunn KM, The Vietnamese concentration in Cabramatta: Site of avoidance and deprivation, or Island of adjustment and participation?, Australian Geographical Studies, 31(2), (1993), 228-245.

8 Gábos A, Gál RI, Kézdi G, The effects of child-related benefits and pensions on fertility by birth order: a test on Hungarian data, Population Studies, 63(3), (2009), 215-231, DOI 10.1080/00324720903215293

9 Goh CT, Building a multiracial nation, Speeches, 1987. In: Tan, J (1995), Joint Government-Malay Community Efforts to Improve Malay Education Achievement in Singapore, Comparative Education, 31(3), http://www.js tor.org/stable/3099708 (03-04-2012).

10 Gopinathan S, Ho WK, Recent developments in education in Singapore, School Effectiveness and School Improvement, 10(1), (1999), 99-117.

11 Gopinathan S, Education and Development in Singapore, In: Tan J, Gopinathan S, Ho WK (eds.), Education in Singapore: A book of readings, Prentice-Hall; Singapore, 1997.

12 György L, Main challenges of Hungarian public education: an international comparison, Acta Oeconomica, accepted for publication: 2012.05.07.

13 Juhari MS, Perceptions of Singaporean Malay-Muslim Youths Participating in Comunity Outreach Programmes: Capacity Building for Critical Thinking, University of Birmingham, 2011, http://etheses.bham.ac.uk/3004/

14 Kassim HBM, Singapore Malays' Attitude Towards Education: A Look At The Impediments To Educational Development, National University of Singapore, 2006, http://scholarbank.nus.edu.sg/bitstream/ha ndle/10635/12980/Singapore/\%20Malays/\%20Attitude/\%20Towa rds/\%20Education. pdf?sequence $=1$

15 Kemény I, Beszámoló a magyarországi cigányok helyzetével foglalkozó, 1971-ben végzett kutatásról, MTA Szociológiai Kutató Intézet; Budapest, 1976.

16 Kertesi G, Kézdi G, Roma Employment in Hungary after the PostCommunist Transition, Economics of Transition, 19(3), (2011), 563-610.

17 Khoo CK, Census of population 1980, Singapore, Department of Statistics; Singapore, 1981.

18 Kobayashi Y, Masalah Melayu di Singapura: The Continuous Strive to Succeed, James Gomes News, accessed 07-02-2012, http://www . jamesgomez news. com/article.php?AID=207

19 Lee KY, Mendaki's task is to raise education of all Malays, Speeches 5, 1982, pp. 42-52. In: Tan, J (1995), Joint Government-Malay Community Efforts to Improve Malay Education Achievement in Singapore, Comparative Education, 31(3), http://www . jstor. org/stable/3099708 (03-04-2012).

20 MBMF, 2009, accessed 04-05-2012, http://infopedia.nl.sg/articl es/SIP_1534_2009-06-23.html

21 Mendaki Annual Report, 2009, http://www.mendaki.org.sg/upload_ files/cuteeditor/Document/Yayasan/\%20Mendaki/\%20AR_lores. pdf

22 Ministry of Education Singapore, Ministry of Education Annual Report 1960, Government Printer; Singapore, 1962.

23 MUIS Annual Report 2010, 2011, http://wWw.muis.gov.sg/cms/abou tus/annual . aspx?id=444/\&terms=annual/\%20report $/ \% 202010$

24 National Library Singapore, Resource Guides, National Library Singapore, accessed 04-04-2012, http://libguides.nl.sg/singapores_educati on_system

25 Neményi Mária, Kis roma demográfia, Amaro Drom, (November 1999), ht tp://www . amarodrom.hu/archivum/99/11/4.html
26 Németh Gy, A cigányok, a rózsadombiak és a Mózes-fajták, (Gypsies, experts from the Rózsadomb, Moses-types), HVG, (29-10-2009), accessed 0103-2011,http://hvg.hu/velemeny/20091029_ciganyvita_felzarko zas_integracio_akadaly

27 Ooi C-S, Soft authoritarianism, political pragmatism and cultural policies: Singapore as a City for the Arts, Creative Encounters Working Paper no. 34, Copenhagen:Imagine. Creative Industry Research Centre, 2009.

28 Parental Involvement in Schools: Child Trends Databank, 2005, accessed 0405-2012, http://www.childtrendsdatabank.org/pdf/39_PDF.pdf

29 Progress of the malay community in Singapore since 1980, Ministry of Community Development, Youth, Sports, 2010, http://app1.mcys.gov.sg/ Portals/0/Summary/research/ProgressofMalayCommunity.pdf

30 Pulay Gy, Benkő J, Báger G, A magyarországi cigányság helyzetének javitására és felemelkedésére a rendszerváltás óta fordított támogatások mértékéról és hatékonyságáról (On the extent and efficiency of subsidies for closing the Roma achievement gap since the economic transition in Hungary), Állami Számvevőszék, Fejlesztési és Módszertani Intézet; Budapest, 2008, http://www.asz.hu/tanulmanyok/2008/a-magyarorszagi-ci ganysag-helyzetenek-javitasara-es-felemelkedesere-a-rends zervaltas-ota-forditott-tamogatasok-merteke-es-hatekonysa ga/t206.pdf

31 Rasheed ZAB, MUIS and MENDAKI: Current and future challanges, No. 5., Department of Malay Studies, National University of Singapore; Singapore, 1992, accessed 19-04-2012, http://www.fas.nus.edu.sg/ malay/publications/working_papers/Muis/\%20/\&/\%20Mendaki/\% 20--/\%20Current/\%20/\&/\%20Future/\%20Challenges.pdf

32 Romano Rácz S, Miért nem integrálódnak a magyarországi romák?, (Why do not integrate Hungarian Roma?), HVG, (14-10-2009), http:// hvg.hu/velemeny/20091014_roma_cigany_integracio (hun). (downloaded: 01-03-2011).

33 Secondary School Education Booklet, 2011, accessed 01-05-2012, http://www.moe.gov.sg/education/secondary/files/seconda ry-school-education-booklet.pdf

34 Sen CS, Speech by Mr Chan Soo Sen, Minister of State for Education $\mathcal{E}$ community development and sports at Mendaki Tuition Scheme Appreciation tea , 2004, accessed 26-04-2012, http://www.moe.gov.sg/media/speec hes/2004/sp20040117a.htm

35 Sharom A, Wong J (eds.), Malay Participation in the National Development of Singapore, Central Council of Malay Cultural Organization; Singapore, 1971.

36 Sim L, Yu S, Han S, Public housing and ethnic integration in Singapore, Habitat International, (2003), 293-307, DOI 10.1016/S01973975(02)00050-4

37 Smith S, The politics of 'Race' and residence: Citizenship, segregation and white supremacy in Britain, Cambridge: Polity Press, 1989.

38 Statistical Tables from Yearbook-Population, 2011, http://www . singstat .gov.sg/pubn/reference/yos11/statsT-demography.pdf

39 Suhaimi N, Contest to solve Malay problems, The Strait Times, Singapore, (2010), 4.

40 Tan J, Joint Government-Malay Community Efforts to Improve Malay Education Achievement in Singapore, Comparative Education, 31(3), (1995), accessed 03-04-2012, 339-354, http://www. jstor.org/stable/3099708 41 The Straits Times: 'an article from the volume of 2007, September.

42 Zahoor ABHFH, Policies and politics in Malay education in Singapore 1951-1965, M.A dissertation; Singapore, 1969. unpublished.

43 Website of Ain Society, 2012, accessed 12-05-2012, http://www . ainsocie ty.org.sg/about/ain-society-history

44 Website of Ain Society, 2012, accessed 12-05-2012, http://www . ainsocie ty.org.sg/services/financial-assistance

45 Website of the AMP, 2012, accessed 07-05-2012, http://www . amp.org.sg /subindex.asp?id=A027_11/\&keyword=mendaki 
46 Website of the AMP, 2012, accessed 10-05-2012, http://www . amp.org.sg /subindex . asp?id=A027_10

47 Website of the AMP, 2012, accessed 08-05-2012, http://www . amp.org.sg /main.asp

48 Website of Mendaki: Education Resources, 2012, accessed 27-042012, http://wWw.mendaki.org.sg/edu-trust-fund/education-r esources.aspx

49 Website of Mendaki Club, 2012, accessed 04-05-2012, http://www .menda kiclub.org.sg/

50 Website of Mendaki-SENSE, 2012, accessed 29-04-2012, http://wWw.me ndaki-sense.com.sg/who.html

51 Website of Rima, 2012, accessed 10-07-2012, http://www.rima.sg/subi ndex . asp?id=A001-08

52 Website of the MUIS, 2011, accessed 29-04-2012, http://www.muis.gov . sg/cms/services/Islamic.aspx?id=117

53 Website of the MUIS, 2011, accessed 12-05-2012, http://www.muis.gov . sg/cms/aboutus/organisation . aspx?id=448

54 Website of the MUIS, 2012, accessed 08-07-2012, http://wWw.muis.gov .sg/cms/aboutus/default.aspx 